\title{
NK Cell Subgroups, Phenotype, and Functions After Autologous Stem Cell Transplantation
}

\author{
Benedikt Jacobs ${ }^{1,2,3}$, Sara Tognarelli,5, Kerstin Poller ${ }^{3}$, Peter Bader ${ }^{4,5}$ \\ Andreas Mackensen ${ }^{3}$ and Evelyn Ullrich ${ }^{3,4,5 *}$
}

${ }^{1}$ Department of Cancer Immunology, Institute for Cancer Research, Oslo University Hospital, Radiumhospital, Oslo, Norway, ${ }^{2}$ The KG Jebsen Center for Cancer Immunotherapy, Institute of Clinical Medicine, University of Oslo, Oslo, Norway, ${ }^{3}$ Department of Haematology and Oncology, University Hospital Erlangen, Erlangen, Germany, ${ }^{4}$ Department of Pediatric Stem Cell Transplantation and Immunology, Children's Hospital, Johann Wolfgang Goethe-University, Frankfurt, Germany, ${ }^{5}$ LOEWE Center for Cell and Gene Therapy, Johann Wolfgang Goethe-University, Frankfurt, Germany

\section{OPEN ACCESS}

Edited by:

Francisco Borrego,

BioCruces Health Research Institute and Cruces University Hospital, Spain

Reviewed by:

Roberto Biassoni,

Istituto Giannina Gaslini, Italy

Jacques Zimmer,

Luxembourg Institute of Health,

Luxembourg

*Correspondence:

Evelyn Ullrich

evelyn.ullrich@kgu.de

Specialty section:

This article was submitted to

NK Cell Biology,

a section of the journal

Frontiers in Immunology

Received: 22 September 2015 Accepted: 02 November 2015 Published: 24 November 2015

Citation:

Jacobs $B$, Tognarelli S, Poller $K$, Bader P, Mackensen A and Ullrich E

(2015) NK Cell Subgroups,

Phenotype, and Functions After

Autologous Stem Cell

Transplantation.

Front. Immunol. 6:583.

doi: 10.3389/fimmu.2015.00583
High-dose chemotherapy with consecutive autologous stem cell transplantation (autoSCT) is a well-established treatment option for patients suffering from malignant lymphoma or multiple myeloma. Natural killer (NK) cells are an important part of the immune surveillance, and their cell number after autoSCT is predictive for progression-free and overall survival. To improve knowledge about the role of NK cells after autoSCT, we investigated different NK cell subgroups, their phenotype, and their functions in patients treated with autoSCT. Directly after leukocyte regeneration (>1000 leukocytes/ $\mu$ l) following autoSCT, CD56 ${ }^{++}$NK cells were the major NK cell subset. Surprisingly, these cells showed unusually high surface expression levels of CD57 and killer lg-like receptors (KIRs) compared to expression levels before or at later time points after autoSCT. Moreover, these NK cells strongly upregulated KIR2DL2/3/S2 and KIR3DL1, whereas KIR2DL1/ $S 1$ remained constant, indicating that this cell population arose from more immature NK cells instead of from activated mature ones. Remarkably, NK cells were already able to degranulate and produce IFN- $\gamma$ and MIP- $1 \beta$ upon tumor interaction early after leukocyte regeneration. In conclusion, we describe an unusual upregulation of CD57 and KIRs on CD56 ${ }^{++}$NK cells shortly after autoSCT. Importantly, these NK cells were functionally competent upon tumor interaction at this early time point.

Keywords: NK cells, CD57, KIR, autologous stem cell transplantation, CD107a expression, IFN- $\gamma$ production

\section{INTRODUCTION}

Natural killer (NK) cells are an important part of the innate immune system and are able to kill virus-infected or malignantly transformed cells (1). Their important role in tumor surveillance has been demonstrated in many different tumor models (1). NK cell cytotoxicity is regulated by a diverse repertoire of inhibitory and activating receptors. Inhibitory receptors, such as killer Ig-like receptors (KIRs) and the C-type lectin-like receptor NKG2A, recognize

Abbreviations: HDC, high-dose chemotherapy; (auto)SCT, (autologous) stem cell transplantation; MM, multiple myeloma; NHL, non-Hodgkin lymphoma; TP1-3, time point 1-3; KIRs, killer Ig-like receptors; NK cell, natural killer cell. 
different alleles of HLA molecules (HLA-A, B, and C by KIRs and HLA-E by NKG2A) on healthy cells. In contrast, many tumor cells downregulate their HLA molecules to evade T cell recognition, making them more susceptible to NK cell killing (2). Additionally, tumor cells may express stress-induced molecules, such as MHC I chain-related molecule A/B or UL-16-binding proteins, which are ligands for the activating NK cell receptor NKG2D $(3,4)$.

High-dose chemotherapy (HDC) with consecutive autologous stem cell transplantation (autoSCT) is an effective and wellestablished treatment option for patients suffering from multiple myeloma (MM) (5) or malignant lymphoma (6-9). Before treatment with the myeloablative chemotherapy, hematopoietic stem cells are collected from peripheral blood and frozen. Following HDC, these cells are thawed and given back to the patient in order to shorten the time of aplasia, thereby reducing the infection and blood transfusion rates.

Many reports have demonstrated the important role of the absolute lymphocyte count after HDC/autoSCT (10). It has been shown that an absolute lymphocyte count $>500 / \mu \mathrm{l}$ is associated with improved overall and progression-free survival in patients with Hodgkin lymphoma (11), non-Hodgkin lymphoma (NHL) (12), acute myeloid leukemia (13), MM (12), and metastatic breast cancer (14). By analyzing the different lymphocyte subsets at day 15 following autoSCT, a clear correlation between improved overall survival and progression-free survival could only be found for NK cell counts $>80 / \mu \mathrm{l}$. No correlation was found for any other lymphocyte subset (15). In a more recent study, improved median overall and progression-free survival as well as the NK cell count at day 15 after HDC/autoSCT were all associated with an increased IL-15 concentration at day 15 of $\geq 76.5 \mathrm{pg} / \mathrm{ml}$ for NHL patients receiving HDC/autoSCT (16).

Because there is no information available regarding the detailed analysis of NK cell subsets or function early after HDC/ autoSCT, in our study, we prospectively investigated the major NK cell subsets directly after leukocyte recovery (leukocytes $>1000 / \mu \mathrm{l}$ ) and also at later time points after HDC/autoSCT in patients with different lymphoproliferative diseases. Moreover, we further analyzed the different NK cell subsets, evaluating their education and differentiation markers, as well as their functional properties, such as cytokine/chemokine production and degranulation capacity.

\section{MATERIALS AND METHODS}

\section{Patients' Characteristics and Study Design}

This study was carried out in accordance with the recommendations of the local ethics committee of the University of Erlangen, and all patients gave written informed consent in accordance with the Declaration of Helsinki. Patients who suffered from $\mathrm{MM}$ or malignant lymphoma and received HDC/autoSCT were included. Blood was taken from these patients at three different time points. Time point 1 (TP1) was before the start of the HDC and at least 3 weeks after the last chemotherapy. The second time point (TP2) was 1-2 days after leukocyte regeneration $(>1000$ leukocytes/ $\mu \mathrm{l}$ ) following autoSCT, and the third time point (TP3) was after at least 2 weeks following leukocyte recovery.

\section{Reagents}

For NK and K562 cell culture, we used full media containing RPMI 1640 media $\left(\right.$ Gibco $\left.^{\circledR}\right)$ supplemented with 10\% FBS, MEM non-essential amino acids (1\%), sodium pyruvate (1\%), L-glutamine (1\%; all from PanBiotech), and penicillin/streptomycin (1\%; Thermo Fischer Scientific). For the washing steps, we used Dulbecco's phosphate-buffered saline (DPBS; Gibco ${ }^{\circledR}$ ).

To analyze the different leukocyte subsets, CD3, CD14, CD16, CD19, CD45, and CD56 antibodies with different fluorochromes from Becton Dickinson (BD) were used. For detailed NK cell subset analyses, we used anti-KIR2D-, KIR3DL1/2-, and KIR2DL1/ S1-PE (Miltenyi), KIR2DL1-PerCP (R\&D), KIR2DL2/3/S2-APC (Beckman Coulter), KIR3DL1 PE-Vio770 (Miltenyi), NKG2A FITC (Miltenyi), and CD57 APC (BD). For the KIR staining, the clones of the antibodies were selected according to Czaja et al. (17), and a sequential staining protocol was used as described by Beziat et al. (18). For intracellular staining, we used IFN- $\gamma$ PE-Cy-7 and MIP-1 $\beta$ APC-H7 (BD). To exclude dead cells, 7-AAD (BD) for extracellular and Fixable Viability Dye eFluor ${ }^{\circledR}$ 520 (eBioscience) for intracellular staining were used.

\section{PBMC Preparation, Freezing, and Thawing}

Blood samples were obtained from the patients at the indicated time points. PBMCs were isolated by performing a Ficoll density centrifugation of whole blood samples, and then the PBMCs were frozen $\left(5 \times 10^{6} \mathrm{PBMCs} / \mathrm{ml}\right.$ freezing media containing $90 \%$ FCS + 10\% DMSO; from Sigma) until they were used.

For thawing, tubes were incubated at room temperature and gently thawed by re-suspending the cells in prewarmed full media (without FCS). The cells were washed twice and counted before being used for further analysis.

\section{Extra- and Intracellular Antibody Staining}

For surface staining, the cells were incubated with different antibody cocktails for $10^{\prime}$ at $4^{\circ} \mathrm{C}$; then, they were washed and either fixed in BD CytoFix ${ }^{\mathrm{TM}}$ solution or further processed for intracellular staining using the BD Cytofix/Cytoperm ${ }^{\mathrm{TM}}$ kit. Briefly, the cells were first incubated for $30^{\prime}$ at $4^{\circ} \mathrm{C}$ with Fixable Viability Dye eFluor $^{\circledR} 520$ (eBioscience), and then they were washed and fixed for $20^{\prime}$ at $4^{\circ} \mathrm{C}$ in $100 \mu \mathrm{BD}$ Cytofix ${ }^{\mathrm{TM}}$ solution. Subsequently, the cells were washed in $\mathrm{BD}$ Cytoperm ${ }^{\mathrm{TM}}$ solution and incubated with the indicated intracellular antibodies for $20^{\prime}$ at $4^{\circ} \mathrm{C}$. Finally, the cells were washed, placed into $\mathrm{BD}$ CytoFix ${ }^{\mathrm{TM}}$ solution, and analyzed with a BD FACSCanto $\mathrm{II}^{\mathrm{TM}}$ or Canto10c ${ }^{\mathrm{TM}}$ using the FlowJo $^{\circledR}$ software (FlowJo, LLC) was used to analyze the FACS data.

\section{Functional Assays}

After thawing, the cells were placed into full media supplemented with 100 IU IL-2/ml (Proleukin ${ }^{\circledR}$, Novartis) in a 96-U well plate overnight. The cells were harvested, washed, counted, and incubated with K562 cells (ratio 1:1) in full media in a 96-U well plate for $4 \mathrm{~h}$. CD107a APC (BD) was added at the start of the 
coculturing period and BD GolgiStop ${ }^{\mathrm{TM}}(\mathrm{BD})$ was added after $1 \mathrm{~h}$ for the rest of the incubation time.

\section{Statistics}

For statistical analysis, we used GraphPad Prism ${ }^{\circledR}$ software. In all graphs, the mean and SD were calculated and plotted. For comparison between matched samples, we used a Wilcoxon test, whereas for non-matched samples, we performed a MannWhitney test. Statistical significance is indicated with the $p$-values $\left({ }^{*}<0.05 ;{ }^{* *}<0.01 ;{ }^{* *}<0.001 ;{ }^{* * * *}<0.0001\right)$.

\section{RESULTS}

\section{Patients' Characteristics and Leukocyte Subsets}

Peripheral blood samples from 32 different patients collected at three specific time points (TP1-3, as described in Section "Materials and Methods") were available for the analysis of leukocyte subsets. The basic patient characteristics are summarized in Table 1. The ratio between male and female patients was approximately $2: 1$. Half of the patients suffered from MM. The average age at HDC/autoSCT was 56.7 years. The average time between SCT and TP2 was 11.6 days, whereas the time between collecting samples at TP2 and TP 3 was 38.8 days. All three values were normally distributed.

Before the start of $\mathrm{HDC} /$ autoSCT at TP1, CD ${ }^{+} \mathrm{CD} 56^{-} \mathrm{T}$ cells and $\mathrm{CD}_{14}{ }^{+}$monocytes were the two major leukocyte subsets in all patients (Figure 1A; for gating strategy, see Figure S1 in Supplementary Material). While $\mathrm{CD} 14^{+}$monocytes were the major subset early after leukocyte recovery after HDC/autoSCT at TP2 (Figures 1A,B), CD3 ${ }^{+} \mathrm{CD} 56^{-} \mathrm{T}$ cells were the major subset at TP3 (Figures 1A,B). In contrast, the NK cell percentages within the leukocyte population significantly decreased from TP1 to TP2 ( $p$-value: 0.0175 ) but recovered to the initial value at TP3 ( $p$-value TP2/TP3: 0.0263; TP1/3: 0.19; Figures 1A,B).

By correlating the NK cell dynamics at the three different time points with clinical data, we observed that the fold change of the NK cell percentage within the leukocyte population between TP1 and TP2 (ratio TP2/TP1) significantly differed between patients having a time period of $\leq 11$ days between SCT and TP2 and those having a period of $>11$ days ( $p$-value: $0.04)$. When the time period was $>11$ days, no decrease in the

\begin{tabular}{ll}
\hline TABLE 1 | Patient characteristics. & \\
\hline Gender & Male (23), female (9) \\
Mean age (range) & 56.7 years (30-74 years) \\
Malignancy & \\
Multiple myeloma & 16 \\
Diffuse large-cell B cell lymphoma & 7 \\
Mantle cell lymphoma & 3 \\
T cell lymphoma & 5 \\
Hodgkin lymphoma & 1 \\
Recurrent/refractory disease at 1 year & $6 / 21$ (5 patients were lost during \\
after SCT (yes/no) & follow-up) \\
Time period SCT-TP2 (mean, days) & 11.6 \\
Time period TP2-TP3 (mean, days) & 38.8
\end{tabular}

NK cell percentage within the leukocyte population at TP2 was observed. Moreover, another significant difference was observed when comparing the fold change in the NK cell percentage between TP1 and TP2 in patients who were refractory/ recurrent or not at 1 year after SCT ( $p$-value: 0.0258$)$. Patients with recurrent or refractory disease did not have a decrease in their fold change ratio (TP2/TP1), while patients without recurrent/refractory disease did have a decrease at 1 year after SCT. Additionally, the fold increase in the NK cell percentage between TP2 and TP3 (TP3/TP2 ratio) was more pronounced when the time period between TP2 and TP3 was $\leq 38$ days ( $p$-value: 0.12; Figure 1C).

No differences were observed when analyzing the patients' age or hematological malignancies in relation to the fold changes of the NK cell percentages within the leukocyte population between the three different time points (Figure S2 in Supplementary Material).

\section{CD56 $^{++} \mathrm{CD}^{-16}{ }^{-/+}$NK Cells are the Major Subset at Leukocyte Recovery}

Next, we analyzed the different NK cell subsets based on their CD56 and CD16 expression. NK cells were divided into $\mathrm{CD} 6^{++} \mathrm{CD} 16^{-}$or $\mathrm{CD} 16^{+}$and $\mathrm{CD} 56^{+} \mathrm{CD} 16^{++} \mathrm{NK}$ cells (see Figure $\mathrm{S} 1$ in Supplementary Material). The $\mathrm{CD} 56^{++} \mathrm{CD} 16^{+}$population has been reported to be an intermediate state between $\mathrm{CD} 56^{++} \mathrm{CD} 16^{-}$ and $\mathrm{CD} 56^{+} \mathrm{CD} 16^{++} \mathrm{NK}$ cells $(19,20)$. The $\mathrm{CD} 56^{+} \mathrm{CD} 16^{-}$population was excluded, as it was shown that this population could be induced by cryopreservation (21).

At TP1, the major $\mathrm{NK}$ cell subset was the $\mathrm{CD} 56^{+} \mathrm{CD} 16^{++}$ $\mathrm{NK}$ cell population $(71.86 \%)$, followed by the $\mathrm{CD} 56^{++} \mathrm{CD} 16^{+}$ (17.71\%) and the $\mathrm{CD}^{2} 6^{++} \mathrm{CD}^{-} 6^{-}(10 \%)$ populations (Figure 2A). After leukocyte regeneration (TP2), the $\mathrm{CD} 56^{+} \mathrm{CD} 16^{++}$cells significantly decreased (39.98\%; $p$-value: $<0.0001)$, whereas both $\mathrm{CD}^{+++} \mathrm{NK}$ cell subsets significantly increased (CD16 ${ }^{-}: 22.85 \%$, p-value: $<0.0001$; CD16 ${ }^{+}: 36.51 \%$, $p$-value: $\left.<0.0001\right)$. At TP3, the levels of $\mathrm{CD} 56^{+} \mathrm{CD} 16^{++} \mathrm{NK}$ cells increased again $(64.85 \%$; $p$-value: $<0.0001)$ but remained reduced in contrast to the starting levels at TP1 ( $p$-value: 0.0064$)$. Conversely, the levels of $\mathrm{CD} 56^{++} \mathrm{CD} 16^{-}$ (14.41\%; $p$-value: 0.0006$)$ and $\mathrm{CD}^{+} 6^{+}(20.66 \%$; $p$-value: $<0.0001)$ cells decreased but remained significantly elevated compared to the starting values [ $p$-values: $0.0184\left(\mathrm{CD}^{-}\right)$and 0.0428 $\left(\mathrm{CD} 16^{+}\right)$; Figure 2B].

The ratio between mature $\mathrm{CD}_{5} 6^{+}$and more immature $\mathrm{CD} 56^{++}$ NK cells, which is approximately 10 within healthy donors (data not shown), was already significantly reduced within our patients before HDC/autoSCT (TP1; ratio: 3.707) because all patients had previously received chemotherapy. Nevertheless, the ratio significantly dropped at TP2 (ratio: 1.157 ; $p$-value: $<0.0001$ ) and did not recover to initial values at TP3 [ratio: $2.49 ; p$-value: 0.0001 (TP2-3); 0.0111 (TP1-3); Figure 2C].

The $\mathrm{CD} 56^{+} / \mathrm{CD}_{5} 6^{++}$ratios at TP2 and TP3 were both independent of the time period between SCT and TP2 ( $\leq 11$ days: 1.247 vs. $>11$ days: 1.041 ; $p$-value: 0.392 ) and between TP2 and TP3 ( $\leq 38$ days: 2.59 vs. $>38$ days: 2.32 ; $p$-value: 0.504 ; Figure 2D). Within the group of $\mathrm{MM}$ patients, the $\mathrm{CD} 56^{+} /$ $\mathrm{CD} 6^{++}$ratio was lower compared to lymphoma patients, but 

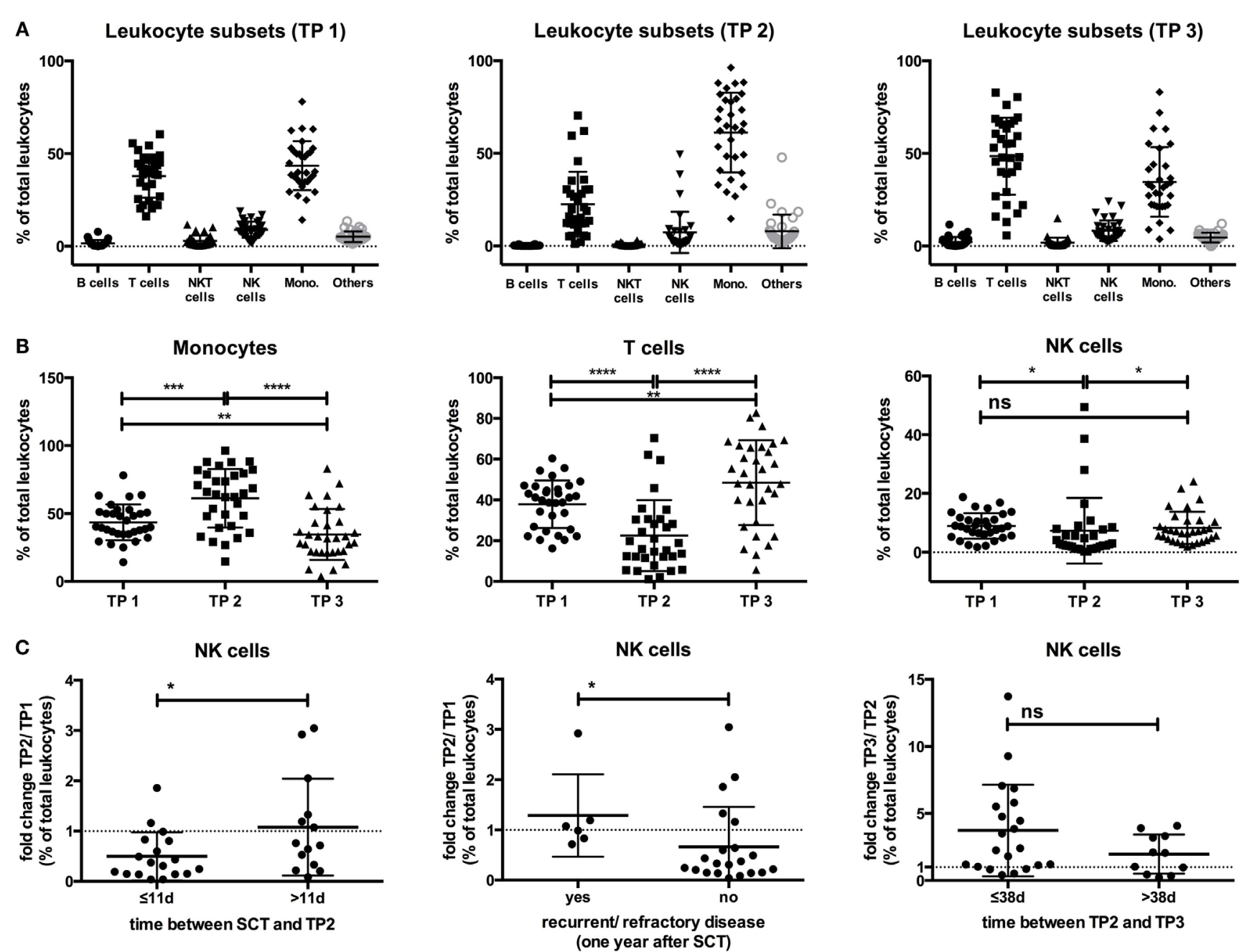

FIGURE 1 | (A) The percentages of the different leukocyte subsets within the leukocyte population at all three time points are indicated. (B) The percentage of $\mathrm{CD} 14^{+}$monocytes within the leukocyte population increased from TP1 (43.49\%) to TP2 (61.22\%; $p$-value: 0.0003), becoming the major leukocyte subset at TP2 but decreased below the starting levels at TP3 (34.6\%; $p$-value TP2/TP3: <0.0001; TP1/3: 0.0088). In contrast, the T cell percentages decreased from TP1 (37.89\%) to TP2 (22.5\%; $p$-value: $<0.0001)$, but they increased again at TP3 (48.49\%) above the initial values to become the major leukocyte subset at TP3 ( $p$-value TP2/TP3: $<0.0001$; TP1/3: 0.0093). The NK cell percentages decreased from TP1 (8.94\%) to TP2 (7.32\%) but reached the initial levels again at TP3 (8.29\%). (C) Patients with a time period of $\leq 11$ days between SCT and TP2 had a decrease from TP1 to TP2 within their NK cell percentage (ratio TP2/TP1: 0.49), in contrast to patients with a time period $>11$ days (ratio TP2/TP1: 1.07). Similarly, patients with no recurrent/refractory disease 1 year after SCT had a decrease of their NK cell percentage at TP2 (ratio TP2/TP1: 0.66), as opposed to patients who were recurrent/refractory at 1 year (ratio TP2/TP1: 1.28). The increase of the NK cell percentage from TP2 to TP3 was more pronounced in patients with a time period of $\leq 38$ days between TP2 and TP3 (ratio TP3/TP2: 3.73 ) than in patients with a time period of $>38$ days (ratio TP3/TP2: 1.97).

it was only significantly lower at TP2 (1.656 vs. 0.6578; $p$-value: 0.0019; Figure 2D). In contrast, the patients' age and relapse/ refractory status at 1 year after autoSCT seemed to have no impact on the $\mathrm{CD} 56^{+} / \mathrm{CD} 56^{++}$ratio at any time point (Figure S3 in Supplementary Material).

\section{Increased Levels of CD57 and KIR Expression After Leukocyte Regeneration}

Next, we analyzed the expression of markers for NK cell education and differentiation at the indicated time points.
As expected, the NKG2A expression on all NK cells increased from TP1 (67.63\%) to TP2 (76.51\%; p-value: 0.0179$)$, and the percentage of $\mathrm{NKG}_{2} \mathrm{~A}^{+} \mathrm{NK}$ cells remained elevated above the starting values until TP3 (77.67\%; p-value: 0.0009). Further NK cell subset analyses revealed that the observed early increase in NKG2A at TP2 was potentially an effect of the elevated $\mathrm{CD} 6^{++}$population expressing higher levels of NKG2A than the $\mathrm{CD} 56^{+} \mathrm{CD} 16^{++}$population because the NKG2A expression did not significantly differ within the distinct subsets between TP1 and TP2. In contrast, the percentage of NKG2A-expressing NK cells was significantly elevated in all subsets at TP3 compared to 

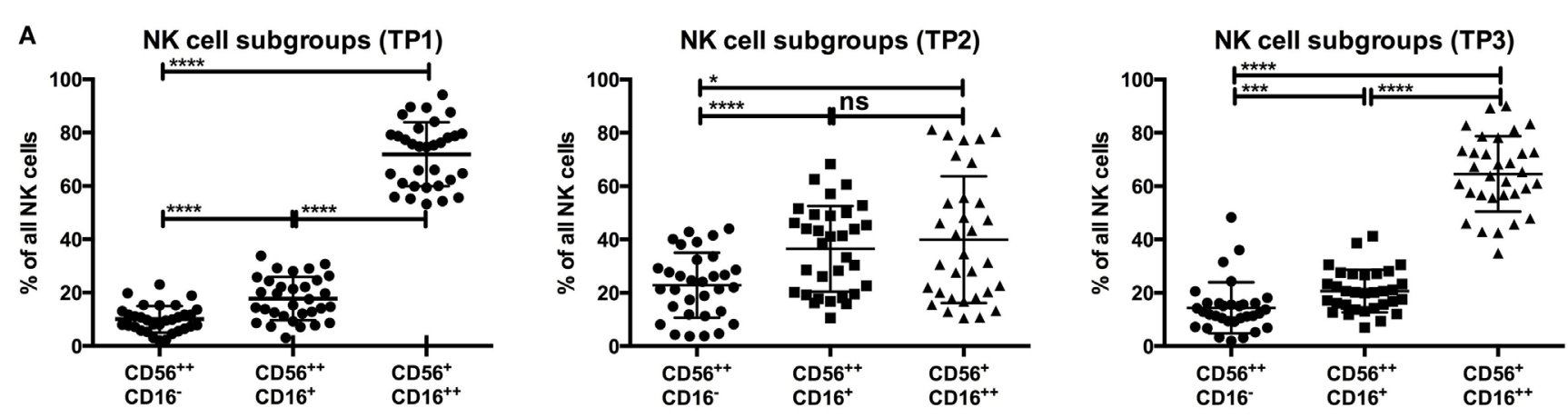

B CD56 ${ }^{++}$CD16- NK cells
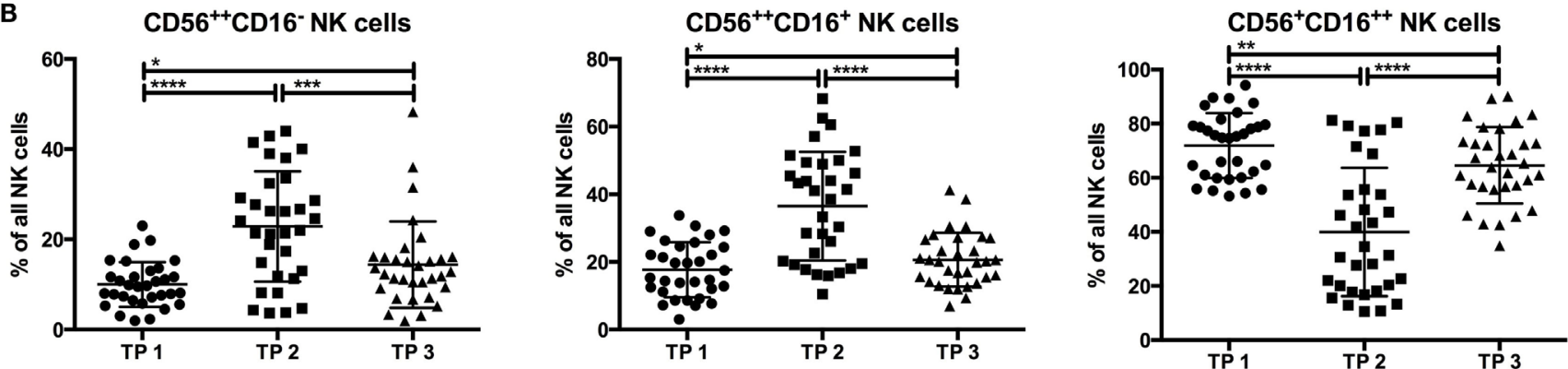

C
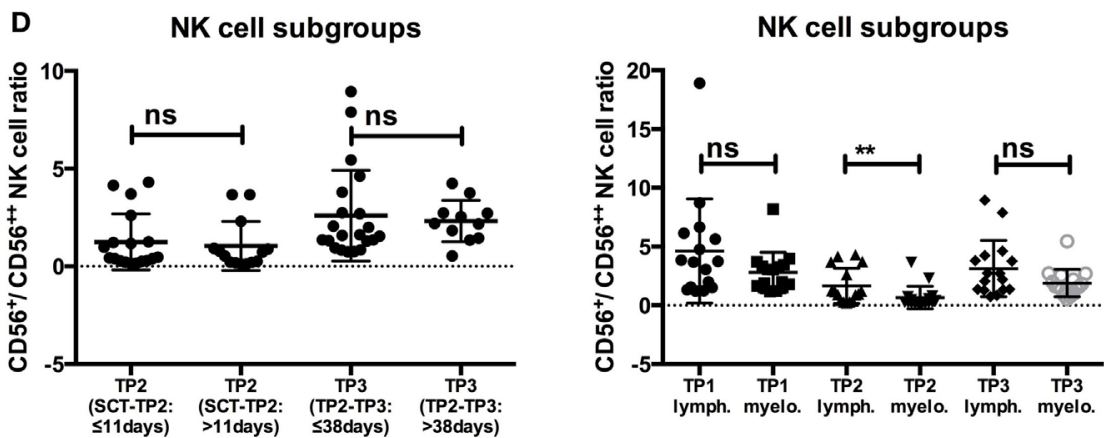

FIGURE 2 | (A,B) The level of CD56+CD16 $6^{++}$NK cells significantly dropped at TP2 (39.98\%) and recovered at TP3 (64.58\%), but it remained lower in contrast to the starting levels (TP1: 71.86\%). Moreover, the percentages of $\mathrm{CD}^{2} 6^{++} \mathrm{CD} 16^{-/+} \mathrm{NK}$ cells were markedly increased at TP2 (CD16-: 22.85\%; CD16+: 36.51\%) and remained elevated at TP3 (CD16-: 14.41\%; CD16+: 20.66\%) compared to the TP1 values (CD16 $:$ 10\%; CD16+: 17.71\%). (C) The ratio of CD56 ${ }^{+} / C D 56^{++}$NK cells at TP1 was already lower than in healthy controls (approx 10; data not shown), with a ratio of 3.707, and decreased further at TP2 (1.157). Although the ratio increased at TP3 (2.49), it was still lower compared to TP1 and healthy control samples. (D) There were no significant differences when analyzing the CD56 ${ }^{+} / \mathrm{CD}^{2} 6^{++}$ ratio at TP2 with regard to the time period between SCT and TP2 ( $\leq 11$ days: 1.247; >11 days: 1.041) or at TP3 with regard to the period between TP2 and TP3 ( $\leq 38$ days: 2.59; $>38$ days: 2.32). A significant difference of the $\mathrm{CD} 56^{+} / \mathrm{CD}^{2} 6^{++}$ratio between lymphoma and myeloma patients was only observed at TP2 (lymphoma patients: 1.656; myeloma patients: 0.6578).

TP1 [p-value: $0.0054\left(\mathrm{CD} 56^{++} \mathrm{CD} 16^{-}\right) ; 0.0259\left(\mathrm{CD}^{2} 6^{++} \mathrm{CD} 16^{+}\right)$; $0.0031\left(\mathrm{CD}^{+} 6^{+} \mathrm{CD} 16^{++}\right)$; Figure 3A].

$\mathrm{CD} 57^{+} \mathrm{NK}$ cells, known to define terminally differentiated $\mathrm{NK}$ cells, significantly increased from TP1 (43.53\%) to TP2 (56.66\%; p-value: 0.0163 ) in all NK cells but decreased to the initial values at TP3 (39.13\%; p-value: 0.4274). Surprisingly, CD57 expression was significantly increased within the $\mathrm{CD} 56^{++} \mathrm{CD} 16^{+-}$population at TP2 (CD16-: 32.98\%; CD16+: 57.78\%, p-value: <0.0001) but decreased again from TP2 to TP3 (CD16-: 5.592\%; $\mathrm{CD}^{+} 6^{+}$: $19.06 \%$, p-value: <0.0001). Nevertheless, the percentage of
$\mathrm{CD} 7^{+}$cells was still elevated in contrast to the starting values at TP1 [CD16-: 4.1\%; CD16 : 15.58\%, p-values: $0.0102\left(\mathrm{CD} 16^{-}\right)$; $\left.0.0214\left(\mathrm{CD} 16^{+}\right)\right]$. CD57 expression within the $\mathrm{CD} 56^{+} \mathrm{CD} 16^{++}$ population was also elevated at TP2 (72.15\%; $p$-value: 0.0006$)$ but to a much lesser extent (Figure 3B).

Strikingly, the percentage of $\mathrm{KIR}^{+} \mathrm{NK}$ cells remained constant over time (TP1: 42.45\%; TP3: 44.09\%; p-value: 0.463), even shortly after leukocyte regeneration (TP2: 40.77\%; $p$-value: $0.4106)$. Of note, the KIR expression within the $\mathrm{CD} 56^{++} \mathrm{CD} 16^{+/-}$ NK cell population was markedly increased at TP2 (CD16 ${ }^{-}$ 


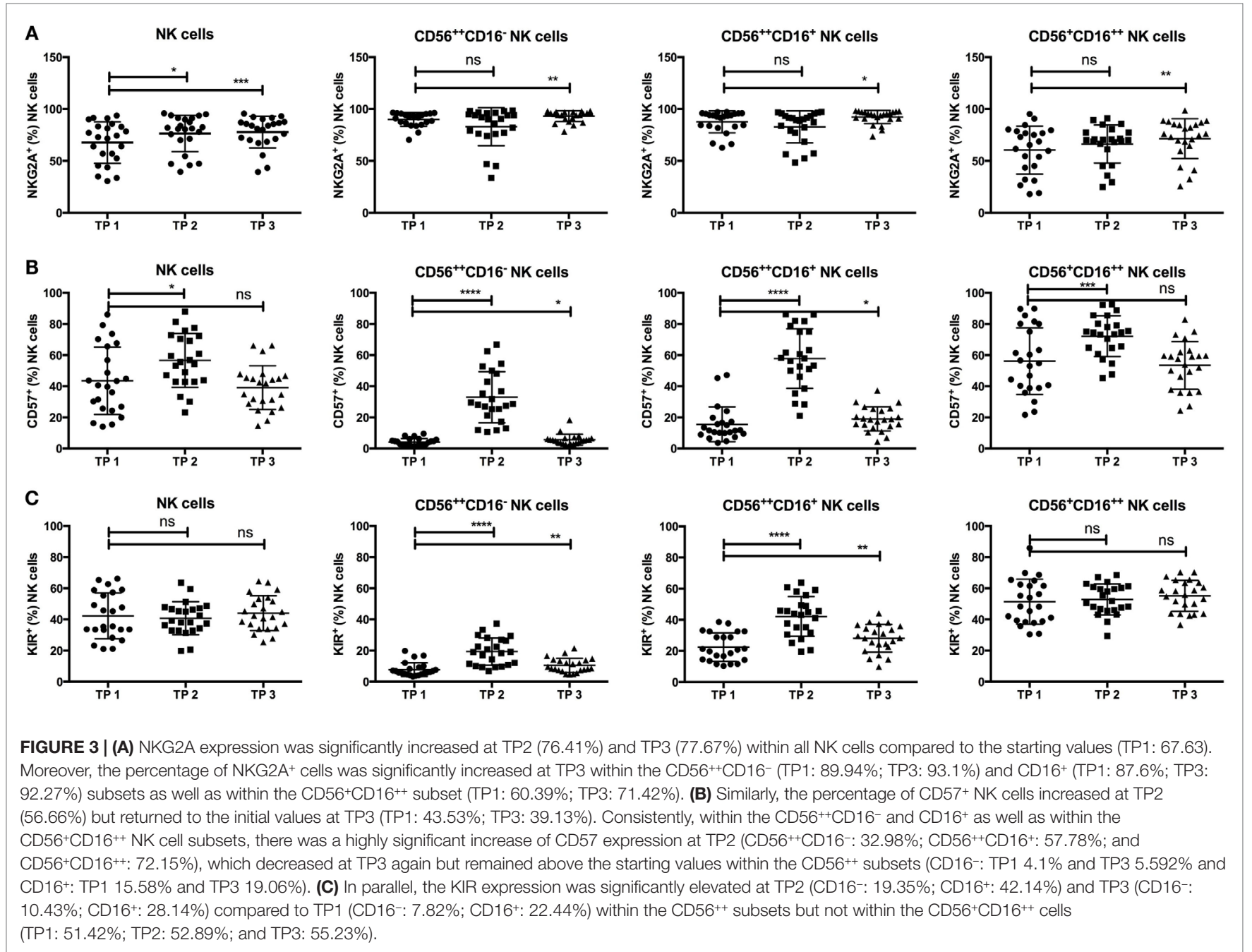

19.35\%; CD16 $6^{+}$42.14\%; $p$-value: $<0.0001$ for both populations) and remained elevated at TP3 (CD16 $: 10.43 \%$; $\left.\mathrm{CD}^{-} 6^{+}: 28.14 \%\right)$ in comparison to the starting values at TP1 [CD16 ${ }^{-}: 7.82 \%$; CD16 ${ }^{+}$: 22.44\%; $p$-values: $\left.0.0083\left(\mathrm{CD} 16^{-}\right) ; 0.0015\left(\mathrm{CD} 16^{+}\right)\right]$. KIR expression within the $\mathrm{CD} 56^{+} \mathrm{CD} 16^{++}$population remained stable throughout all time points (TP1: $51.42 \%$, TP2: $52.89 \%$, and TP3: $55.23 \%$; Figure 3C).

\section{Elevated CD57 and KIR Expression is Age Dependent}

Additionally, we analyzed the influence of different clinical factors on the expression levels of NKG2A, CD57, and KIRs within the different NK cell subsets. As CD57 expression levels within healthy individuals are known to be age dependent (22), we compared CD57 expression within the younger ( $\leq 56$ years) and older ( $>56$ years) patient populations. Notably, there was a significant difference in the percentage of $\mathrm{CD} 57^{+}$cells within the CD $56^{++} \mathrm{CD}^{-} 6^{-}$population at TP2 ( $\leq 56$ years: $23.98 \%$; $>56$ years: 42.8\%; p-value: 0.0056$)$, whereas this effect was not observed within the $\mathrm{CD} 56^{++} \mathrm{CD} 16^{+}$or the $\mathrm{CD} 56^{+} \mathrm{CD} 16^{++}$population (Figure 4A).

Similar, byanalyzing KIR expression within the $\mathrm{CD} 56^{++} \mathrm{CD} 16^{+/-}$ populations, we observed a significant difference in their expression at TP2 between the two age groups [ $\leq 56$ years: $14.74 \%$ $\left(\mathrm{CD} 16^{-}\right)$and $37.29 \%\left(\mathrm{CD} 16^{+}\right)$; $>56$ years: $24.39 \%\left(\mathrm{CD} 16^{-}\right)$and 47.44\% (CD16 $\left.{ }^{+}\right)$; p-values: $\left.0.0088\left(\mathrm{CD}_{16}{ }^{-}\right), 0.0317\left(\mathrm{CD} 16^{+}\right)\right]$. No age-dependent difference was found for KIR expression within the $\mathrm{CD} 56^{+} \mathrm{CD} 16^{++}$population at TP2 but at TP3 ( $\leq 56$ years: 50.51\%; > 56 years: 60.37\%; $p$-value: 0.0225; Figure 4B).

In contrast, there was no difference in NKG2A expression throughout all age groups, time points, or NK cell populations (Figure 4C).

We also addressed CD57, KIR, and NKG2A expressions in different subsets with regard to recurrent/refractory disease at 1 year after SCT and hematological malignancy. There were no differences in the expression of the three markers regarding the rate of relapsed/refractory disease throughout all NK cell subsets and time points, except for CD57 expression at TP1 within the $\mathrm{CD} 6^{++} \mathrm{CD} 16^{-} \mathrm{NK}$ cell population, which was higher in patients 


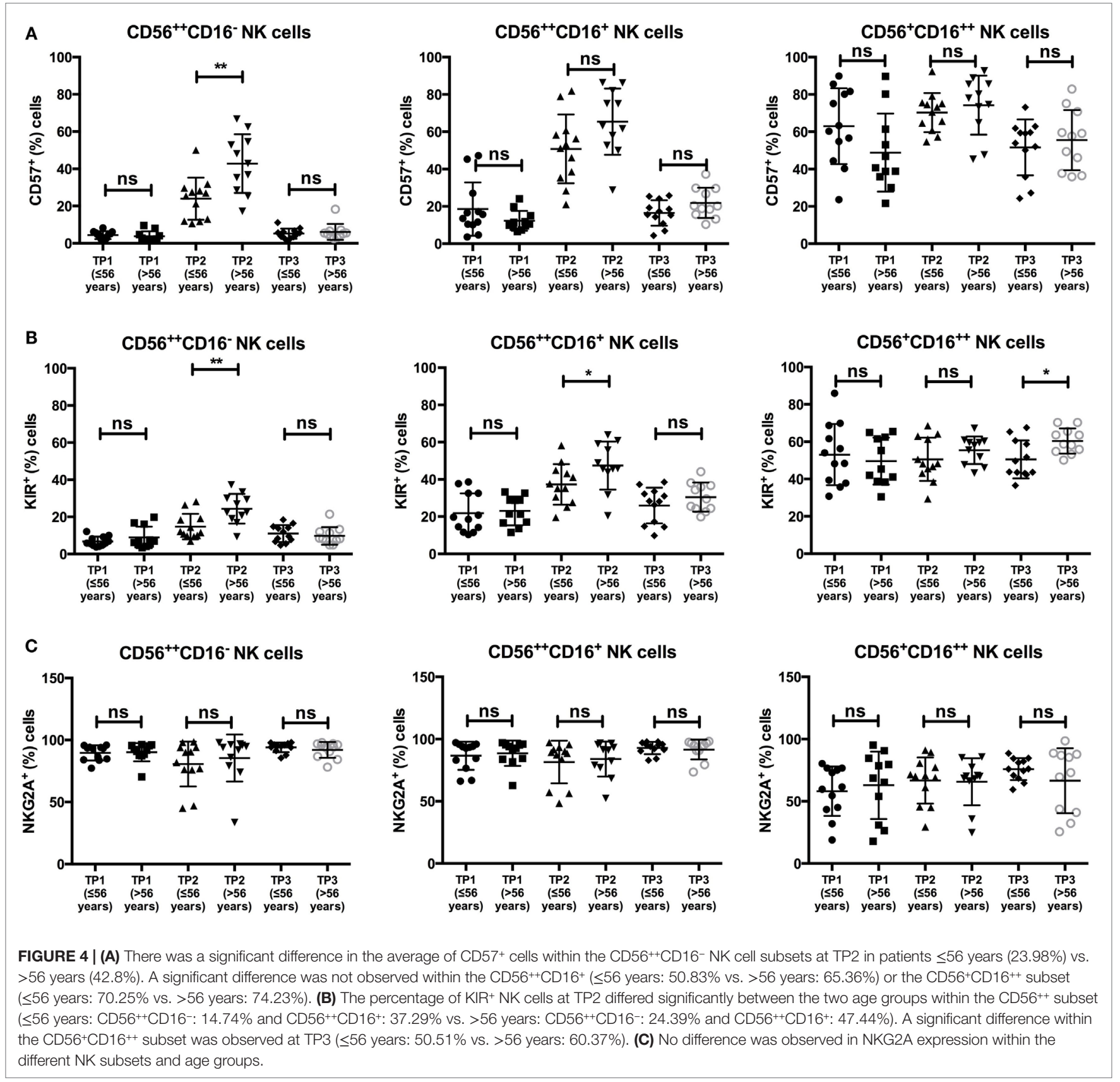

with no recurrent/refractory disease 1 year after SCT ( $p$-value: 0.0083; Figure S4A in Supplementary Material).

Furthermore, patients with MM had higher NKG2A expression within the $\mathrm{CD} 56^{++} \mathrm{CD} 16^{-/+}$subset at $\mathrm{TP} 2$ compared to lymphoma patients. No further differences were observed (Figure S4B in Supplementary Material).

\section{Detailed KIR Expression Analysis}

We next performed an extended KIR analysis within the samples of five additional patients, who were not included into the original analysis group because we did not have a sample from TP3. We analyzed the expression levels and distribution of global
KIR expression (anti-KIR2D and anti-KIR3DL1/2), as well as KIR2DL1/S1, KIR2DL2/3/S2, and KIR3DL1, within the different subsets at TP1 and TP2. Notably, global KIR expression levels were upregulated within both $\mathrm{CD} 6^{++} \mathrm{NK}$ cell populations at TP2 compared to TP1, whereas they remained stable within the CD $56^{+} \mathrm{CD} 16^{++} \mathrm{NK}$ cell population, confirming the results from the former analyzed patient cohort (Figures 5A-C). Within the $\mathrm{CD} 56^{+} \mathrm{CD} 16^{++}$population, no clear differences between the expression levels of the different KIR subsets were observed comparing TP1 and TP2 (Figure 5C). In contrast, both CD56 $6^{++}$ NK cell subsets upregulated their KIR2DL2/3/S2 and KIR3DL1 expression levels from TP1 to TP2, whereas the KIR2DL1/S1 levels 


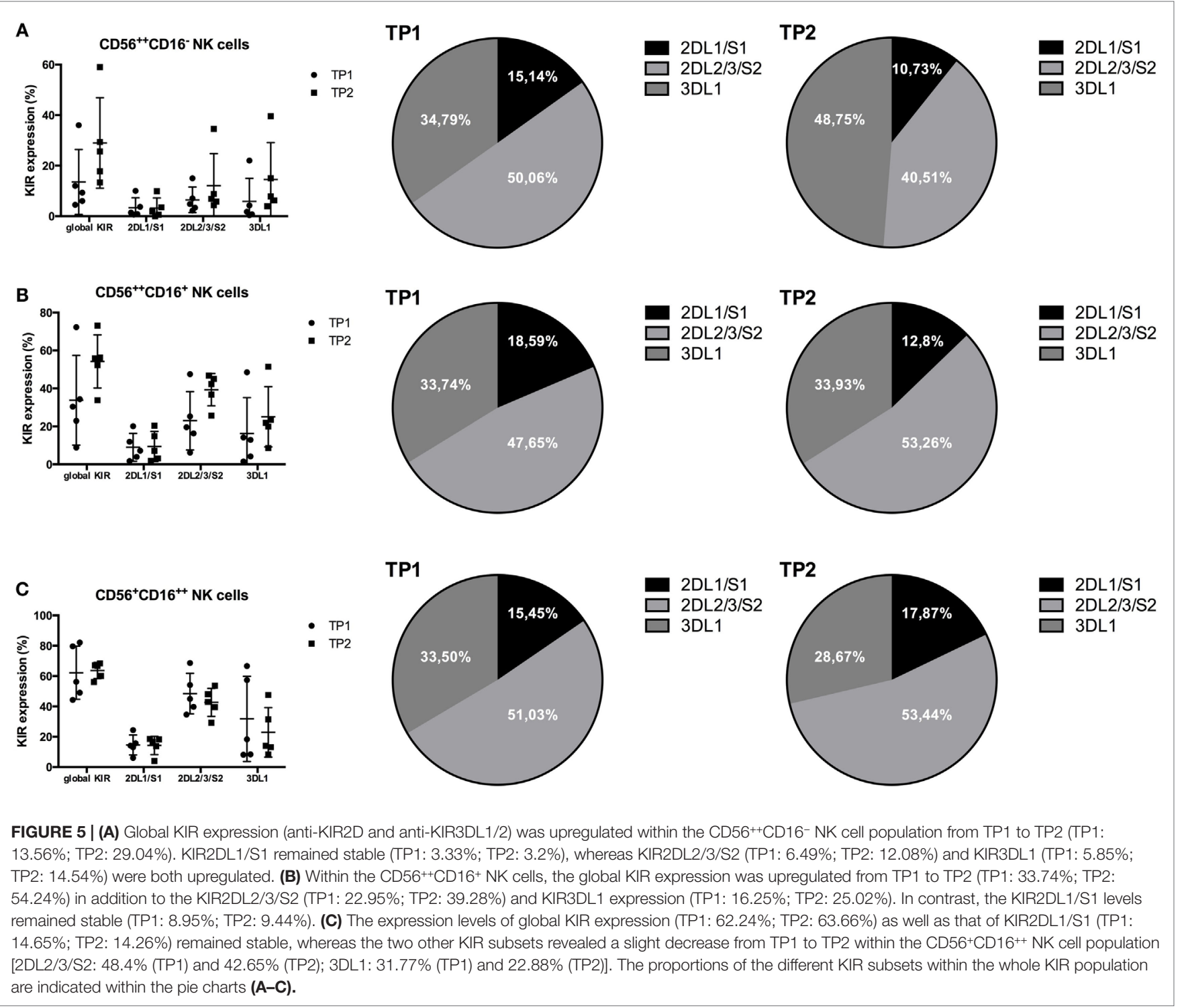

remained stable between the two time points (Figures $5 \mathbf{A}, \mathbf{B}$ ). Moreover, the proportion of the different KIR subsets within the global KIR population changed within the $\mathrm{CD} 56^{++} \mathrm{CD} 16^{-}$ population, with KIR2DL2/3/S2 being the dominant KIR subset at TP1 and KIR3DL1 being the dominant one at TP2 (Figure 5A; pie chart). Within the $\mathrm{CD} 56^{++} \mathrm{CD} 16^{+}$population, KIR2DL2/3/S2 was the dominant KIR population at TP1 and was the only one to increase from TP1 to TP2 (Figure 5B; pie chart).

\section{NK Cell Function is Preserved After Leukocyte Recovery}

Finally, we analyzed the functions of the different NK cell subsets at the three time points before and after HDC/autoSCT. After an overnight incubation with low-dose IL-2 (100 IU/ml) and $4 \mathrm{~h}$ of coculture with K562 cells, we investigated the cytokine (IFN- $\gamma$ ) and chemokine (MIP-1 $\beta$ ) productions, as well as the NK cell degranulation (CD107a expression) capacity (for gating strategy see Figure S5 in Supplementary Material). Due to very low cell numbers at TP2, functional analysis was only possible in a subset of all included patients $(n=17)$.

As expected, $\mathrm{CD} 56^{++} \mathrm{CD} 16^{-} \mathrm{NK}$ cells were the main subset to produce IFN- $\gamma$ upon interaction with $\mathrm{K} 562$ cells at all three time points (Figure 6A). The percentage of IFN- $\gamma$-positive $\mathrm{CD} 6^{++} \mathrm{CD} 16^{-} \mathrm{NK}$ cells was slightly decreased at TP2 compared to TP1 but significantly increased from TP2 to TP3 ( $p$-value: 0.0008). Similarly, MIP-1 $\beta$ - and CD107a-positive CD $56^{++} \mathrm{CD} 16^{-}$ cells remained constant between TP1 and TP2, whereas their percentages increased from TP2 to TP3 [ $p$-values: 0.0056 (MIP$1 \beta)$ and 0.0232 (CD107a)].

Whereas IFN- $\gamma$ production was only marginal at all three time points within the $\mathrm{CD} 56^{++} \mathrm{CD} 16^{+} \mathrm{NK}$ cell population (Figure 6B), MIP-1 $\beta$ - and CD107a-positive cells had similar percentages at TP1 and TP2. Both percentages significantly increased from TP2 to TP3 ( $p$-value: 0.0079 for both). 

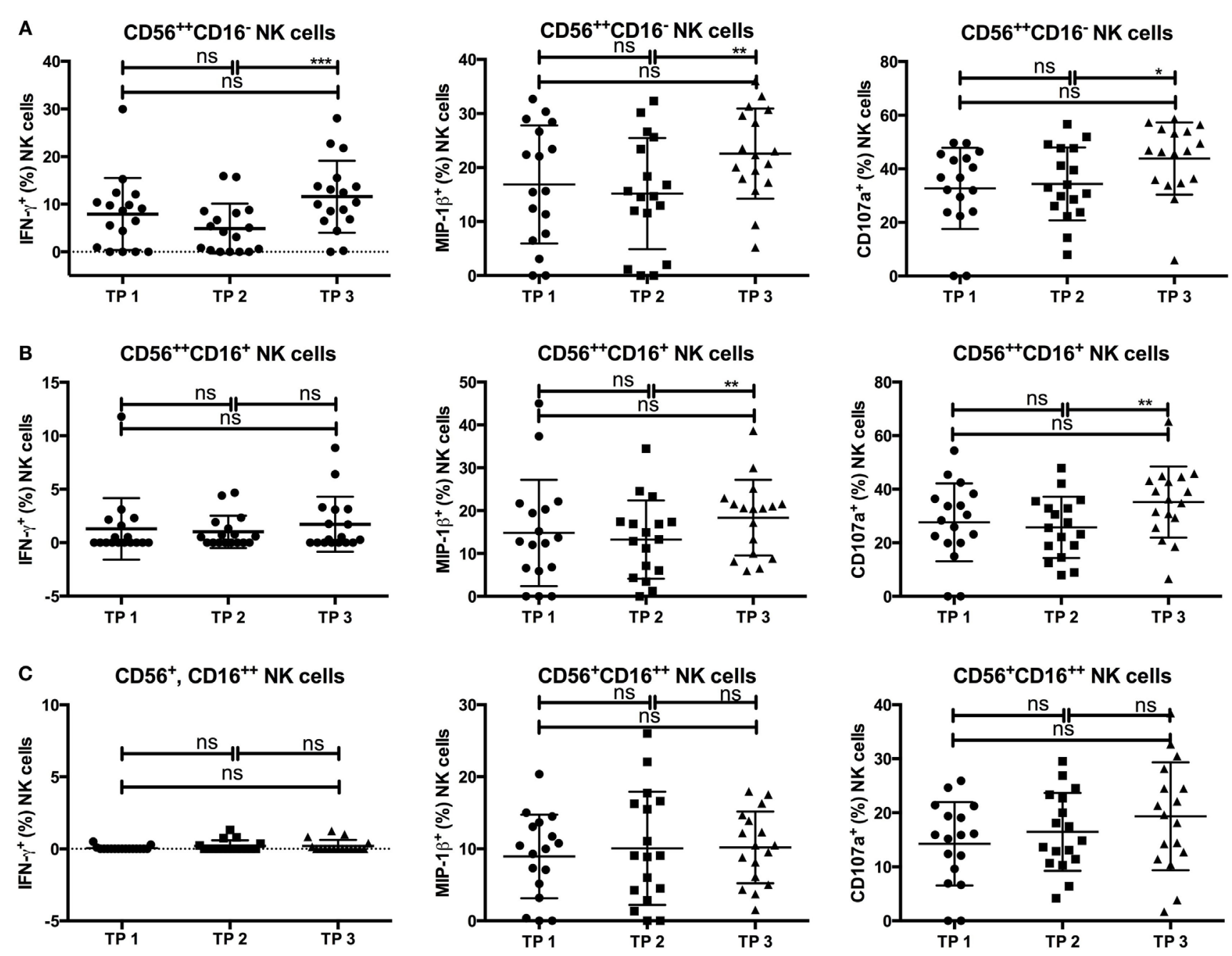

D $\quad \mathrm{CD}^{++} 6^{+C D 16-N K}$ cells
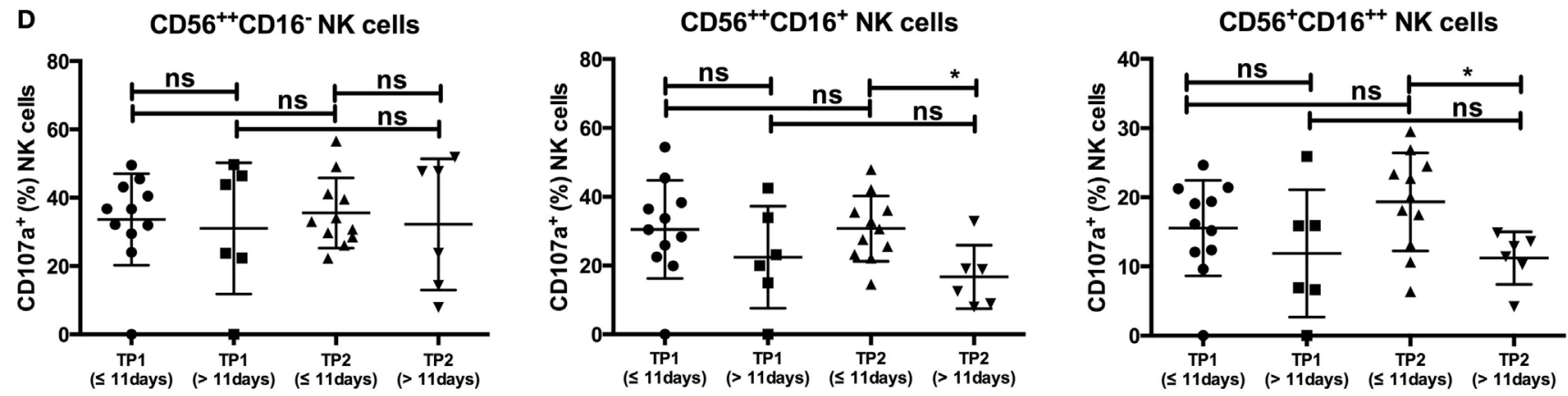

FIGURE 6 | (A) The CD56++CD16- subset revealed an increase of IFN- $\gamma-$, MIP-1 $\beta$-, and CD107a-positive cells between TP2 and TP3 [TP2: $4.9 \%$ (IFN- $\gamma$ ), $15.17 \%$

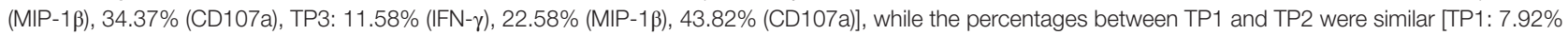

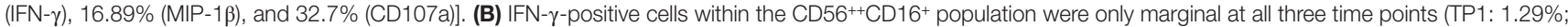

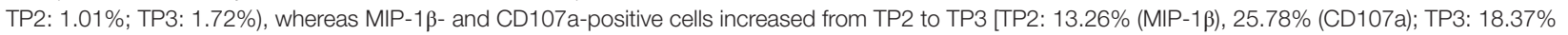

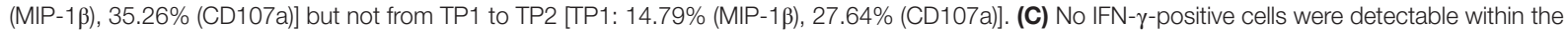
CD56 ${ }^{+}$CD $16^{++}$population at any of the three time points. MIP-1 $\beta$-positive cells remained stable throughout all three time points (TP1: 8.93\%; TP2: 10.06\%; TP3: 10.18\%) which is similar to CD107a-expressing cells (TP1: 14.26\%; TP2: 16.47\%; TP3: 19.33\%). (D) Patients were grouped according to the duration between SCT and TP2 ( $\leq 11$ vs. $>11$ days). While there were no differences between the percentage of CD107a-expressing cells within the CD56 $6^{++}$CD16- population at TP1 and TP2, the percentage of CD107a-positive NK cells at TP2 was lower within patients with a longer duration between SCT and TP2 within the CD56 ${ }^{++} \mathrm{CD}_{16}{ }^{+}$

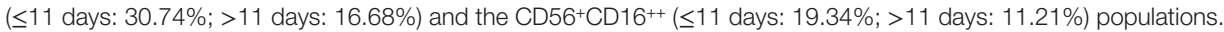


Within the $\mathrm{CD} 56^{+} \mathrm{CD} 16^{++} \mathrm{NK}$ cell subsets, the percentage of MIP-1 $\beta$ - and CD107a-positive NK cells after coincubation with K562 cells remained constant at all three time points, whereas no IFN- $\gamma$-positive NK cells were detected at any time point (Figure 6C).

Although the number of available patient samples was low, we tried to correlate the NK cell function values with clinical data. Remarkably, there was an impact of the duration from SCT to TP2 ( $\leq 11$ vs. $>11$ days), as the percentage of CD107a-positive cells within the $\mathrm{CD} 56^{++} \mathrm{CD} 16^{+}$and $\mathrm{CD} 56^{+} \mathrm{CD} 16^{++}$populations was significantly lower when the time period between SCT and TP2 exceeded 11 days [ $p$-values: $0.0111\left(\mathrm{CD} 56^{++} \mathrm{CD} 16^{+}\right) ; 0.027$ $\left(\mathrm{CD} 56^{+} \mathrm{CD} 16^{++}\right)$; Figure 6D]. In investigating age-dependent differences ( $\leq 56$ vs. $>56$ years), we observed that patients older than 56 years tended to have slightly higher percentages of IFN- $\gamma$ - and MIP-1 $\beta$-positive $\mathrm{CD} 56^{++} \mathrm{CD} 16^{-}$cells at TP1, although the difference was not significant. Furthermore, no significant differences in the presence of MIP-1 $\beta$ - or CD107a-positive CD56 ${ }^{++} \mathrm{CD} 16^{+}$ or $\mathrm{CD}_{56}{ }^{+} \mathrm{CD} 16^{++} \mathrm{NK}$ cells between the two age groups were observed at all three time points, although older patients tended to have lower CD107a expression within the $\mathrm{CD} 56^{+} \mathrm{CD} 16^{++}$ subset at TP3 ( $p$-value: 0.074$)$. Notably, the observed increase of CD107a-positive CD56 ${ }^{+} \mathrm{CD} 16^{++}$cells from TP2 to TP3 was only present in younger but not older patients [ $\leq 56$ years: $15.69 \%$ (TP2) and $24.05 \%$ (TP3), $p$-value: 0.1 ; $>56$ years: $17.16 \%$ (TP2) and $15.14 \%$ (TP3), p-value: 0.82; Figure S6 in Supplementary Material].

\section{DISCUSSION}

In the setting of HDC/autoSCT, it has been demonstrated that a rapid NK cell recovery at 1 month after HDC/autoSCT is associated with a prolonged progression-free survival in MM (23) and NHL patients (16). In those studies, the absolute NK cell count (cells/ $\mu \mathrm{l}$ ) at 1 month or 15 days after HDC/autoSCT was investigated, whereas in our study, we analyzed the NK cell percentage within the leukocyte population in correlation with the day of leukocyte recovery following autoSCT.

Our data demonstrate that the percentage of NK cells within the leukocyte population decreased after leukocyte recovery but increased to the initial levels over time. Notably, when the time period between SCT and TP2 was $>11$ days, indicating a delay in leukocyte recovery, the decrease within the NK cell percentage was lower. This may be explained by the fact that leukocyte recovery (white blood cell count $>1000 / \mu \mathrm{l}$ ) after SCT is mainly due to the recovery of neutrophil granulocytes (10), and their recovery can be delayed in contrast to NK cell recovery (24). Moreover, the higher increase of the NK cell percentage from TP2 to TP3 in patients from whom the third blood sample was collected $\leq 38$ days after TP2 indicates that the NK cell percentage within the leukocytes increases much more within the first month after leukocyte recovery and then decreases again. Similar results have been demonstrated by Rueff et al. by analyzing the absolute NK cell count numbers (cells/ $\mu$ l) 1, 3, 6, 12, and 24 months after SCT. Here, the NK cell numbers first increased 1 month after SCT, but then they decreased again until 6 months after SCT (23). The absence of a decrease in the NK cell percentage at TP2 within patients with recurrent/refractory disease at 1 year after SCT could be explained by the fact that most of these patients $(4 / 6$; $66.6 \%$ ) had a time period of $>11$ days from SCT to TP2, unlike non-relapsing/refractory patients $(8 / 21 ; 38 \%)$.

In line with other NK cell reconstitution studies after SCT (24-26), we observed elevated percentages of the more immature CD $56^{++} \mathrm{CD} 16^{+/-} \mathrm{NK}$ cell subsets shortly after SCT, decreasing only slowly at later time points. As the ratio between $\mathrm{CD} 56^{+} /$ CD $56^{++}$NK cells did not differ with shorter ( $\leq 38$ days) or longer ( $>38$ days) time periods between TP2 and TP3, we assume that normalization of the NK cell subset distribution takes much longer than the recovery of the NK cell numbers. Similar observations have been made within patients receiving an allogeneic SCT after reduced-intensity conditioning (26). The conditioning and former treatment regimens could explain the different $\mathrm{NKG}_{2} \mathrm{~A}^{+}$ NK cells ratios between myeloma and lymphoma patients at TP2.

Moreover, the percentage of $\mathrm{NKG}_{2} \mathrm{~A}^{+} \mathrm{NK}$ cells was increased after $\mathrm{HDC} /$ autoSCT and remained high even after several months, as it has been recently demonstrated by Pical-Izard et al. after allogeneic SCT (26). In contrast, we could demonstrate a highly significant increase of $\mathrm{CD}^{+} 7^{+}$and $\mathrm{KIR}^{+} \mathrm{NK}$ cells, mainly within the $\mathrm{CD} 6^{++} \mathrm{CD} 16^{+/-}$subsets at TP2. This effect has not been described thus far within the literature because most of the studies have evaluated NK cell subsets 1 month after SCT (23-27). At this time point, the percentage of $\mathrm{CD} 57^{+}$and $\mathrm{KIR}^{+}$ NK cells had already decreased back toward normal levels within our study group. The prolonged immature phenotype in the Pical-Izard study may be attributed to GVHD prophylaxis, especially cyclosporine A (CSA). Vukicevic et al. investigate the NK cell phenotype at an equally early time point after allogeneic stem cell transplantation as we did but did not detect an upregulation of KIRs within the $\mathrm{CD} 6^{++}$subsets (28), which might be due to the allogeneic transplantation setting. Acquisition of CD57 and KIRs as well as downregulation of NKG2A has been demonstrated as signs of NK cell differentiation and maturation (22). It is known that CD57 expression increases with age within the $\mathrm{CD}_{56}{ }^{+} \mathrm{CD} 16^{++}$population (29), whereas we did not observe any age-related differences within this NK cell subset at any time point. Nevertheless, an age-dependent difference was observed at TP2 within the $\mathrm{CD} 56^{++} \mathrm{CD} 16^{-}$population.

Therefore, the question arises whether these $\mathrm{CD}_{56}{ }^{++}$cells described here represent more mature new NK cells or are just activated "old" NK cells that might have increased their CD56 expression and lost CD16 on their surface. As this phenotype is reset after at least 2 weeks after leukocyte regeneration, one could argue that the phenotype shift is due to the cytokine milieu during HDC/autoSCT. Indeed, there have been several reports about increased cytokine concentrations during allogeneic and autologous SCT $(16,25,30)$ shaping the NK cell phenotype. It has been reported that $\mathrm{CD} 56^{+} \mathrm{CD} 16^{++} \mathrm{NK}$ cells are capable of up-regulating CD56 expression upon IL-15 (28) or IL-12 stimulation (31), of which IL-15 is known to be increased during HDC/autoSCT (16). Furthermore, different groups demonstrated a downregulation of CD16 by metalloproteinases, which can be induced by IL-2 $(32,33)$. In general, the combined effect 
of CD56 upregulation upon IL-15 stimulation and the loss of CD16 through IL-2-stimulated upregulation of metalloproteinases might result in the observed $\mathrm{CD}_{5} 6^{++} \mathrm{CD} 16^{+/-} \mathrm{NK}$ cell phenotype at TP2. Nevertheless, the $\mathrm{CD} 56^{++} \mathrm{NK}$ cells described in our study upregulated KIR3DL1 and KIR2DL2/3/S2, while KIR2DL1/S1 remained stable. KIR3DL1 and KIR2DL2/3 are the first KIRs expressed after SCT, whereas KIR2DL1 is upregulated quite late $(34,35)$. Therefore, we could assume that the KIR upregulation was due to the generation of "fresh/new" NK cells and was not due to a shift of "old" NK cells to a CD56 $6^{++}$ phenotype because we should have observed no changes within the KIR subtype distribution between TP1 and TP2 if the cells were derived from the "old" NK population. Moreover, we observed a slight upregulation of CX3CR1 at TP2 (data not shown). CX3CR1 expression is associated with a more mature and differentiated NK cell phenotype within healthy donors (36). In contrast to the observed CD56 upregulation, which can be explained by IL-15 stimulation (28), CX3CR1 is known to be downregulated upon IL-15 stimulation (36), which contradicts the idea that $\mathrm{CD}^{2} 6^{++} \mathrm{NK}$ cells with a mature phenotype (CD57 ${ }^{+}$, $\mathrm{CX} 3 \mathrm{CR}^{+}$, and $\mathrm{KIR}^{+}$) have arisen from $\mathrm{CD} 56^{\text {dim }} \mathrm{NK}$ cells. In future studies, it would be very interesting to investigate which factors are responsible for this NK cell phenotype because protocols for inducing NK cell maturation and differentiation have yet to be optimized.

Most importantly, we analyzed NK cell functional activity directly after leukocyte recovery after HDC/autoSCT. Upon interaction with K562 tumor cells, the percentage of IFN- $\gamma$ - and MIP-1 $\beta$-positive CD $56^{++} \mathrm{CD} 16^{+/-} \mathrm{NK}$ cells did not differ between TP1 and TP2. This result demonstrates that NK cells are capable of recognizing tumor cells and inducing cytokine and chemokine production, even at a very early time point after HDC/autoSCT. Moreover, the degranulation capacity of the $\mathrm{CD} 56^{+} \mathrm{CD} 16^{++} \mathrm{NK}$ cell subset, known to be mainly responsible for NK cell cytotoxicity (37), remained stable throughout the whole time period until TP3, indicating that these NK cells were able to kill tumor cells at an early time point after SCT. This finding is consistent with other studies in which patients received allogeneic SCT. For example, in the setting of HLA-matched SCT after reducedintensity conditioning, it has been demonstrated that the NK cell degranulation and chemokine production capacity was similar to healthy controls as early as 1 month after SCT. In contrast to our data, IFN- $\gamma$ production upon interaction with K562 cells was significantly reduced after SCT compared to healthy donors (26). These differences might be due to the use of immunosuppressive drugs such as CSA because it has been demonstrated that CSA is able to reduce IFN- $\gamma$ production upon target-cell interaction (38), although a recent report has failed to demonstrate such an effect (39). Furthermore, we compared IFN- $\gamma$ production upon interaction with K562 cells before and after SCT and not directly with healthy control samples. Therefore, although we did not observe a significant decrease in IFN- $\gamma$-positive cells between TP1 and TP2, their percentage might be still significantly lower than in healthy controls. Additionally, we observed that the degranulation capacity was influenced by the time period between SCT and TP2 because patients with a time period $>11$ days had significantly reduced $\mathrm{CD} 107 \mathrm{a}$-positive $\mathrm{CD} 56^{+} \mathrm{CD} 16^{++}$cells at TP2. Because the prolonged time from SCT to TP2 indicates a longer period for leukocyte recovery, this might give an explanation for the reduced degranulation capacity. Nevertheless, we could not discover a correlation between NK cell function at TP2 and the rate of recurrent/refractory disease at 1 year after SCT, which might be due to the low number of recurrent/refractory patients and the short follow-up period.

To the best of our knowledge, this is the first study investigating NK cell function at such an early time point after HDC/ autoSCT. We were able to demonstrate that NK cells were capable of cytokine/chemokine production and degranulation upon tumor cell interaction. Furthermore, we describe an unusual $\mathrm{CD} 6^{++} \mathrm{NK}$ cell population expressing high levels of CD57 and KIRs shortly after SCT. Further analysis and characterization of this population might reveal more details about how NK cell maturation and differentiation are regulated.

\section{AUTHOR CONTRIBUTIONS}

All authors critically revised the work for important intellectual content and approved the final version of the manuscript. They all agreed to be accountable for all aspects of the work in ensuring that questions related to the accuracy or integrity of any part of the work are appropriately investigated and resolved. BJ, ST, and $\mathrm{KP}$ were responsible for acquisition, analysis, and interpretation of the data. EU, PB, AM, and BJ were responsible for the concept and design of the work.

\section{ACKNOWLEDGMENTS}

We thank Franziska Ganss for working with the patient samples during the first phase of the study. We are grateful to the Department of Haematology and Oncology physician team for collecting blood samples from the patients. The authors thank Becton Dickinson (BD) for providing the FACSCanto II ${ }^{\mathrm{TM}}$ and Canto10c ${ }^{\mathrm{TM}}$ Flow Cytometry Analyzers used in this study.

\section{FUNDING}

Authors were supported by the German Cancer Aid (Max Eder Nachwuchsgruppe, Deutsche Krebshilfe; EU), the LOEWE Center for Cell and Gene Therapy Frankfurt (EU, ST, and PB) funded by the Hessian Ministry of Higher Education, Research and the Arts, Germany (III L 4-518/17.004) and by the "Alfred- und Angelika Gutermuth-Stiftung," Frankfurt, Germany (EU). BJ was funded by a Mildred Scheel postdoctoral scholarship from the Dr. Mildred Scheel Foundation for Cancer Research of the German Cancer Aid Organization. ST was founded by a GO-IN postdoctoral fellowship (PCOFUND-GA-2011-291776).

\section{SUPPLEMENTARY MATERIAL}

The Supplementary Material for this article can be found online at http://journal.frontiersin.org/article/10.3389/fimmu.2015.00583 


\section{REFERENCES}

1. Vivier E, Tomasello E, Baratin M, Walzer T, Ugolini S. Functions of natural killer cells. Nat Immunol (2008) 9(5):503-10. doi:10.1038/ni1582

2. Ljunggren HG, Karre K. Host resistance directed selectively against H-2deficient lymphoma variants. Analysis of the mechanism. J Exp Med (1985) 162(6):1745-59. doi:10.1084/jem.162.6.1745

3. Nash WT, Teoh J, Wei H, Gamache A, Brown MG. Know thyself: NK-cell inhibitory receptors prompt self-tolerance, education, and viral control. Front Immunol (2014) 5:175. doi:10.3389/fimmu.2014.00175

4. Ullrich E, Koch J, Cerwenka A, Steinle A. New prospects on the NKG2D/ NKG2DL system for oncology. Oncoimmunology (2013) 2(10):e26097. doi:10.4161/onci.26097

5. Shah N, Callander N, Ganguly S, Gul Z, Hamadani M, Costa L, et al. Hematopoietic stem cell transplantation for multiple myeloma: guidelines from the American Society for blood and marrow transplantation. Biol Blood Marrow Transplant (2015) 21(7):1155-66. doi:10.1016/j. bbmt.2015.03.002

6. Perales MA, Ceberio I, Armand P, Burns LJ, Chen R, Cole PD, et al. Role of cytotoxic therapy with hematopoietic cell transplantation in the treatment of Hodgkin lymphoma: guidelines from the American Society for blood and marrow transplantation. Biol Blood Marrow Transplant (2015) 21(6):971-83. doi:10.1016/j.bbmt.2015.02.022

7. Chen Y, Wang M, Romaguera J. Current regimens and novel agents for mantle cell lymphoma. Br J Haematol (2014) 167(1):3-18. doi:10.1111/bjh.13000

8. Habermann TM. New developments in the management of diffuse large B-cell lymphoma. Hematology (2012) 17(Suppl 1):S93-7. doi:10.1179/10245 3312X13336169156014

9. Perrone G, Corradini P. Autologous stem cell transplantation for T-cell lymphomas. Semin Hematol (2014) 51(1):59-66. doi:10.1053/j. seminhematol.2013.11.002

10. Visani G, Lemoli R, Tosi P, Martinelli G, Testoni N, Ricci P, et al. Use of peripheral blood stem cells for autologous transplantation in acute myeloid leukemia patients allows faster engraftment and equivalent disease-free survival compared with bone marrow cells. Bone Marrow Transplant (1999) 24(5):467-72. doi:10.1038/sj.bmt.1701920

11. Porrata LF, Inwards DJ, Micallef IN, Ansell SM, Geyer SM, Markovic SN. Early lymphocyte recovery post-autologous haematopoietic stem cell transplantation is associated with better survival in Hodgkin's disease. Br J Haematol (2002) 117(3):629-33. doi:10.1046/j.1365-2141.2002.03478.x

12. Porrata LF, Gertz MA, Inwards DJ, Litzow MR, Lacy MQ, Tefferi A, et al. Early lymphocyte recovery predicts superior survival after autologous hematopoietic stem cell transplantation in multiple myeloma or non-Hodgkin lymphoma. Blood (2001) 98(3):579-85. doi:10.1182/blood.V98.3.579

13. Porrata LF, Litzow MR, Tefferi A, Letendre L, Kumar S, Geyer SM, et al. Early lymphocyte recovery is a predictive factor for prolonged survival after autologous hematopoietic stem cell transplantation for acute myelogenous leukemia. Leukemia (2002) 16(7):1311-8. doi:10.1038/sj.leu.2402503

14. Porrata LF, Ingle JN, Litzow MR, Geyer S, Markovic SN. Prolonged survival associated with early lymphocyte recovery after autologous hematopoietic stem cell transplantation for patients with metastatic breast cancer. Bone Marrow Transplant (2001) 28(9):865-71. doi:10.1038/sj.bmt.1703236

15. Porrata LF, Inwards DJ, Ansell SM, Micallef IN, Johnston PB, Gastineau DA, et al. Early lymphocyte recovery predicts superior survival after autologous stem cell transplantation in non-Hodgkin lymphoma: a prospective study. Biol Blood Marrow Transplant (2008) 14(7):807-16. doi:10.1016/j. bbmt.2008.04.013

16. Porrata LF, Inwards DJ, Micallef IN, Johnston PB, Ansell SM, Hogan WJ, et al. Interleukin-15 affects patient survival through natural killer cell recovery after autologous hematopoietic stem cell transplantation for non-Hodgkin lymphomas. Clin Dev Immunol (2010) 2010:914945. doi:10.1155/2010/914945

17. Czaja K, Borer AS, Schmied L, Terszowski G, Stern M, Gonzalez A. A comprehensive analysis of the binding of anti-KIR antibodies to activating KIRs. Genes Immun (2014) 15(1):33-7. doi:10.1038/gene.2013.58

18. Beziat V, Traherne J, Malmberg JA, Ivarsson MA, Bjorkstrom NK, Retiere C, et al. Tracing dynamic expansion of human NK-cell subsets by high-resolution analysis of KIR repertoires and cellular differentiation. Eur J Immunol (2014) 44(7):2192-6. doi:10.1002/eji.201444464

19. Beziat V, Duffy D, Quoc SN, Le Garff-Tavernier M, Decocq J, Combadiere B, et al. CD56brightCD16+ NK cells: a functional intermediate stage of NK cell differentiation. J Immunol (2011) 186(12):6753-61. doi:10.4049/ jimmunol.1100330

20. Romagnani C, Juelke K, Falco M, Morandi B, D’Agostino A, Costa R, et al. CD56brightCD16- killer Ig-like receptor- NK cells display longer telomeres and acquire features of CD56dim NK cells upon activation. J Immunol (2007) 178(8):4947-55. doi:10.4049/jimmunol.178.8.4947

21. Lugthart G, van Ostaijen-ten Dam MM, van Tol MJ, Lankester AC, Schilham MW. CD56(dim)CD16(-) NK cell phenotype can be induced by cryopreservation. Blood (2015) 125(11):1842-3. doi:10.1182/blood-2014-11-610311

22. Bjorkstrom NK, Riese P, Heuts F, Andersson S, Fauriat C, Ivarsson MA, et al. Expression patterns of NKG2A, KIR, and CD57 define a process of CD56dim NK-cell differentiation uncoupled from NK-cell education. Blood (2010) 116(19):3853-64. doi:10.1182/blood-2010-04-281675

23. Rueff J, Medinger M, Heim D, Passweg J, Stern M. Lymphocyte subset recovery and outcome after autologous hematopoietic stem cell transplantation for plasma cell myeloma. Biol Blood Marrow Transplant (2014) 20(6):896-9. doi:10.1016/j.bbmt.2014.03.007

24. Bosch M, Dhadda M, Hoegh-Petersen M, Liu Y, Hagel LM, Podgorny P, et al. Immune reconstitution after anti-thymocyte globulin-conditioned hematopoietic cell transplantation. Cytotherapy (2012) 14(10):1258-75. doi:10.3109 /14653249.2012.715243

25. Dulphy N, Haas P, Busson M, Belhadj S, Peffault de Latour R, Robin M, et al. An unusual CD56(bright) CD16(low) NK cell subset dominates the early posttransplant period following HLA-matched hematopoietic stem cell transplantation. J Immunol (2008) 181(3):2227-37. doi:10.4049/ jimmunol.181.3.2227

26. Pical-Izard C, Crocchiolo R, Granjeaud S, Kochbati E, Just-Landi S, Chabannon C, et al. Reconstitution of natural killer cells in HLA-matched HSCT after reduced-intensity conditioning: impact on clinical outcome. Biol Blood Marrow Transplant (2015) 21(3):429-39. doi:10.1016/j.bbmt.2014.11.681

27. Foley B, Cooley S, Verneris MR, Curtsinger J, Luo X, Waller EK, et al. NK cell education after allogeneic transplantation: dissociation between recovery of cytokine-producing and cytotoxic functions. Blood (2011) 118(10):2784-92. doi:10.1182/blood-2011-04-347070

28. Vukicevic M, Chalandon Y, Helg C, Matthes T, Dantin C, Huard B, et al. CD56bright NK cells after hematopoietic stem cell transplantation are activated mature NK cells that expand in patients with low numbers of T cells. Eur J Immunol (2010) 40(11):3246-54. doi:10.1002/eji.200940016

29. Nielsen CM, White MJ, Goodier MR, Riley EM. Functional significance of CD57 expression on human NK cells and relevance to disease. Front Immunol (2013) 4:422. doi:10.3389/fimmu.2013.00422

30. Boyiadzis M, Memon S, Carson J, Allen K, Szczepanski MJ, Vance $\mathrm{BA}$, et al. Up-regulation of NK cell activating receptors following allogeneic hematopoietic stem cell transplantation under a lymphodepleting reduced intensity regimen is associated with elevated IL-15 levels. Biol Blood Marrow Transplant (2008) 14(3):290-300. doi:10.1016/j. bbmt.2007.12.490

31. Loza MJ, Perussia B. The IL-12 signature: NK cell terminal CD56+high stage and effector functions. J Immunol (2004) 172(1):88-96. doi:10.4049/ jimmunol.172.1.88

32. Harrison D, Phillips JH, Lanier LL. Involvement of a metalloprotease in spontaneous and phorbol ester-induced release of natural killer cell-associated Fc gamma RIII (CD16-II). J Immunol (1991) 147(10):3459-65.

33. Peruzzi G, Femnou L, Gil-Krzewska A, Borrego F, Weck J, Krzewski K, et al. Membrane-type 6 matrix metalloproteinase regulates the activation-induced downmodulation of CD16 in human primary NK cells. J Immunol (2013) 191(4):1883-94. doi:10.4049/jimmunol.1300313

34. Giebel S, Dziaczkowska J, Czerw T, Wojnar J, Krawczyk-Kulis M, Nowak I, et al. Sequential recovery of NK cell receptor repertoire after allogeneic hematopoietic SCT. Bone Marrow Transplant (2010) 45(6):1022-30. doi:10.1038/ bmt.2009.384

35. Fischer JC, Ottinger H, Ferencik S, Sribar M, Punzel M, Beelen DW, et al. Relevance of $\mathrm{C} 1$ and $\mathrm{C} 2$ epitopes for hemopoietic stem cell transplantation: role 
for sequential acquisition of HLA-C-specific inhibitory killer Ig-like receptor. J Immunol (2007) 178(6):3918-23. doi:10.4049/jimmunol.178.6.3918

36. Hamann I, Unterwalder N, Cardona AE, Meisel C, Zipp F, Ransohoff $\mathrm{RM}$, et al. Analyses of phenotypic and functional characteristics of CX3CR1-expressing natural killer cells. Immunology (2011) 133(1):62-73. doi:10.1111/j.1365-2567.2011.03409.x

37. Freud AG, Caligiuri MA. Human natural killer cell development. Immunol $\operatorname{Rev}(2006)$ 214:56-72. doi:10.1111/j.1600-065X.2006.00451.x

38. Eissens DN, Van Der Meer A, Van Cranenbroek B, Preijers FW, Joosten I. Rapamycin and MPA, but not CsA, impair human NK cell cytotoxicity due to differential effects on NK cell phenotype. Am J Transplant (2010) 10(9):1981-90. doi:10.1111/j.1600-6143.2010.03242.x

39. Derniame S, Perazzo J, Lee F, Domogala A, Escobedo-Cousin M, Alnabhan $\mathrm{R}$, et al. Differential effects of mycophenolate mofetil and cyclosporine A on peripheral blood and cord blood natural killer cells activated with interleukin-2. Cytotherapy (2014) 16(10):1409-18. doi:10.1016/j.jcyt.2014.05.010

Conflict of Interest Statement: The authors declare that the research was conducted in the absence of any commercial or financial relationships that could be construed as a potential conflict of interest.

Copyright (C) 2015 Jacobs, Tognarelli, Poller, Bader, Mackensen and Ullrich. This is an open-access article distributed under the terms of the Creative Commons Attribution License (CC BY). The use, distribution or reproduction in other forums is permitted, provided the original author(s) or licensor are credited and that the original publication in this journal is cited, in accordance with accepted academic practice. No use, distribution or reproduction is permitted which does not comply with these terms. 